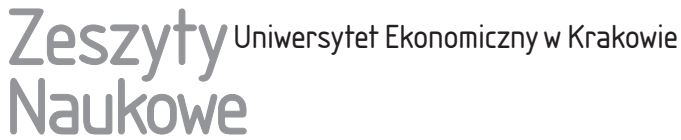

\section{Zastosowanie rachunku kosztów działań na przykładzie wybranego przedsiębiorstwa}

\section{Streszczenie}

W ostatnich latach można zauważyć wzrost zainteresowania problematyką rachunku ABC. Zmieniające się otoczenie i wysoki stopień złożoności procesów wytwórczych sprawiają, że informacje dostarczane przez tradycyjne systemy rachunku kosztów nie zawsze są adekwatne do potrzeb decyzyjnych. Istnieje zatem konieczność wdrożenia takich systemów i rozwiązań w zakresie rachunku kosztów, które dostarczałyby informacji nie tylko szybko, ale przede wszystkim wiarygodnych. Celem artykułu jest zaprezentowanie teoretycznych rozwiązań dotyczących rachunku kosztów działań, a w szczególności przedstawienie zasad projektowania i wdrażania systemu ABC oraz jego przydatności W warunkach funkcjonowania polskich przedsiębiorstw, a także próba zastosowania rachunku kosztów działań w przedsiębiorstwie owocowo-spożywczym. W pracy przedstawiono wyniki badań w zakresie praktycznego zastosowania rachunku kosztów działań w wybranym przedsiębiorstwie.

Słowa kluczowe: rachunkowość zarządcza, rachunek działań, rachunek ABC, rachunkowość finansowa, sprawozdawczość.

Klasyfikacja JEL: M41.

Katarzyna Mokrzycka, Uniwersytet Ekonomiczny w Krakowie, Wydział Finansów i Prawa, Katedra Rachunkowości Finansowej, ul. Rakowicka 27, 31-510 Kraków, e-mail: mokrzyck@uek. krakow.pl 


\section{Wprowadzenie}

Szybko zmieniające się otoczenie i duża złożoność procesów wytwórczych sprawiają, że informacje dostarczane przez tradycyjne systemy rachunku kosztów nie zawsze są adekwatne do potrzeb decyzyjnych. Księgowi, menedżerowie i analitycy finansowi wyrażają przekonanie o konieczności wdrożenia takich systemów i rozwiązań w zakresie rachunku kosztów, które dostarczałyby informacji nie tylko szybko, ale przede wszystkim wiarygodnych. Oczekuje się, że w najbliższych latach nowoczesne koncepcje rachunku kosztów staną się strategiczną koniecznością wielu polskich jednostek gospodarczych (Stępień 2011, s. 842-891).

Warunkiem wykorzystania walorów informacyjnych, potencjalnie tkwiących w systemie rachunku kosztów działań, jest jego wkomponowanie w całokształt rozwiązań systemowych wspomagających proces decyzyjny w przedsiębiorstwie. System rachunku kosztów działań należy zatem projektować, zwracając uwagę na identyfikację oraz analizę procesów jako najważniejszy element systemu. Prawidłowe określenie i analiza procesów zachodzących w przedsiębiorstwie pozwalają osiągnąć pełną skuteczność oraz efektywność informacyjną rachunku kosztów opartego na działaniach.

Głównym celem artykułu jest próba wdrożenia rachunku kosztów działań w wybranym przedsiębiorstwie branży owocowo-spożywczej. Celami szczegółowymi są: ukazanie miejsca i roli rachunku kosztów działań w zarządzaniu przedsiębiorstwem $\mathrm{w}$ gospodarce rynkowej, przedstawienie zasad projektowania i wdrażania systemu ABC oraz jego przydatności w warunkach funkcjonowania polskich przedsiębiorstw, a także zaprezentowanie i omówienie wyników badań empirycznych otrzymanych przez autorkę, dotyczących rachunku kosztów działań w wybranym przedsiębiorstwie branży owocowo-spożywczej.

W świetle przeprowadzonych badań można sformułować tezę, że sprawność procesu gospodarczego w jednostce gospodarczej zależy od efektywnego przebiegu wielu działań. Sterowanie działaniami może przyczyniać się do redukowania kosztów prowadzonej działalności oraz zapewniać bardziej efektywne świadczenie usług. Do weryfikacji tej tezy wykorzystano takie narzędzia badawcze, jak: analiza literatury przedmiotu, obserwacja bezpośrednia, analiza zjawisk i synteza wyników. W niniejszym artykule zaprezentowano jedynie wybrane aspekty wyodrębniania działań w jednostce gospodarczej. Skonstruowany przez autorkę model zarządzania kosztami w przedsiębiorstwie może być wykorzystany do dalszego doskonalenia zarządzania w przedsiębiorstwie poprzez zastosowanie rachunku kosztów działań. 


\section{Istota rachunku kosztów działań}

Każda działalność gospodarcza wymaga ponoszenia kosztów. W racjonalnie kierowanej jednostce gospodarczej oczekiwania dotyczące wysokości kosztów stanowią punkt wyjścia wszystkich procesów planowania i zarządzania. Prowadzenie firmy z wykorzystaniem tradycyjnego rachunku kosztów jest jednak w obecnych warunkach gospodarczych często niewystarczające do podejmowania decyzji zarządczych. W takiej sytuacji właściwym narzędziem pomiaru kosztów staje się rachunek kosztów działań, nazywany również rachunkiem kosztów ABC (activity based costing). Do powstania rachunku kosztów działań przyczyniły się:

- rozwój nowych technologii, automatyzacja i informatyzacja procesów produkcyjnych,

- wzrost znaczenia jakości, zróżnicowanie produktów, zróżnicowanie sposobów obsługi klientów,

- dynamiczny wzrost konkurencji i zmiany w organizacjach wynikające z globalizacji rynku.

Wymienione czynniki doprowadziły do zmian w strukturze kosztów ponoszonych przez jednostkę gospodarczą. Gwałtowny wzrost pośrednich kosztów wytwarzania obejmujących np. koszty amortyzacji i utrzymania jakości nie znajdował odzwierciedlenia w istniejących modelach rachunku kosztów.

Pod koniec lat 80. XX w. amerykańscy naukowcy R.S. Kaplan i R. Cooper zaproponowali nowy model rachunku kosztów pod nazwą activity based costing (ABC). Jego niemieckim odpowiednikiem jest rachunek kosztów procesu (Prozesskostenrechnung), opracowany przez P. Horvatha i R. Mayera. O ile rachunek ABC w Stanach Zjednoczonych powstał pod wpływem niedostatków amerykańskiej rachunkowości w zakresie podstawowej działalności, o tyle niemiecki Prozesskostenrechnung zmierzał do rozwiązywania problemów z zakresu rozliczania kosztów sfery zarządzania i sprzedaży (Piechota 2005, s. 23). Rachunek kosztów procesów to całościowa koncepcja podejścia do obserwacji, ewidencji i rozliczania wspólnych kosztów stałych (Januszewski 2005, s. 35).

Rachunek kosztów działań pozwala na integrację z innymi systemami informacyjnymi. Pełne zespolenie trzech systemów może spowodować różne niepożądane skutki, które wynikają głównie ze zdominowania takiego zintegrowanego układu przez sprawozdawczość zewnętrzną, a więc system regulowany prawem i normami środowiskowymi, co do istoty konserwatywny i abstrahujący od wewnętrznych potrzeb przedsiębiorstwa.

Sprawne i efektywne zarządzanie na wyższych i średnich szczeblach wymaga odpowiedniej informacji o rodzaju, liczbie, jakości i efektywności, w tym o kosztach wykonywanych zadań. Osiagnięcie takiego celu możliwe jest dzięki zastosowaniu rachunku kosztów działań. Rachunek ABC polega na pomiarze, ewidencji 
oraz grupowaniu kosztów według działań dotyczących wytworzenia i sprzedaży wyrobów gotowych.

Rachunek kosztów działań to podstawowa metoda zarządzania oparta na analizie działań. Umożliwia on określenie poziomu i zmian kosztów wynikających ze szczegółowej analizy działań. Wykorzystywanie rachunku ABC pozwala na dostosowanie się przedsiębiorstwa do zmian otoczenia, poprzez wyciąganie wniosków ze zdiagnozowanych odstępstw od wzorcowych działań (Buk 2006, s. 124-125).

W kalkulacji kosztów wytworzenia oraz kosztów jednostkowych pomocny jest rachunek kosztów w układzie kalkulacyjnym, z wyjątkiem tych kosztów, które są pochodnymi innych (koszty pośrednie). Luka ta zostaje wypełniona przez zastosowanie rachunku kosztów działań. Podstawową zasadą jest wyodrębnienie w przedsiębiorstwie głównych działań, gdyż tworzenie nadmiaru informacji generuje niepotrzebne koszty. Wykorzystanie rachunku kosztów ABC daje możliwość nie tylko ustalenia kosztu działania czy procesu, ale również kosztu jednostkowego wyrobu. Rachunek ten ma więc cechy rachunku pełnego (Rybicka 2011, s. 134-134).

Rachunek kosztów w planowaniu i kontroli powinien obejmować zarządzanie zasobami przedsiębiorstwa w trakcie wykonywania działań podstawowych oraz pomocniczych. Rachunek kosztów działań to rachunek zużycia zasobów. Pozwala on bardziej efektywnie niż w wypadku rachunku kosztów stałych czy zmiennych wdrożyć proces planowania i kontroli. Uwzględnia kształtowanie się kosztów na poziomie działań, a ponadto daje możliwość analizy stałych skokowych. Rozważając zarządzanie kosztami działań, należy podzielić podstawowe zasoby na:

- elastyczne - nabywane przez jednostkę gospodarczą systematycznie, w miarę zapotrzebowania, koszty zależą od wielkości zużycia,

- zaangażowane - nazywane sztywnymi, nabywane w sposób nieciągły, wielkość dopasowywana jest do bieżącego zapotrzebowania.

Korzyściami płynącymi z wykorzystywania rachunku kosztów działań z punktu widzenia planowania i kontroli są:

- eliminacja lub minimalizacja kosztów niewpływających na tworzenie wartości dodanej,

- wprowadzenie systemów podnoszących wydajność i efektywność przez rozszerzenie tej działalności, która tworząc koszty, jednocześnie przyczynia się do tworzenia wartości dodatkowej,

- usunięcie zniekształceń danych finansowych spowodowanych błędną alokacją i w rezultacie dostarczenie wiarygodnej informacji, warunkującej sprawne zarządzanie jednostką gospodarczą (Klimczuk 2008),

- uzyskanie informacji o rzeczywistych kosztach wytwarzania poszczególnych produktów, a zwłaszcza o ich zróżnicowaniu, 
- optymalizacja wielu procesów pod względem występujących w ich wyniku relacji między nakładami i korzyściami m.in. poprzez podejmowanie na ich podstawie analizy portfelowej, controllingu procesów, analizy wartości (Buk 2006, s. 131; Naruć, Nowak i Wieloch 2008, s. 222).

Do korzyści wynikających ze stosowania metody ABC należy ustalenie rozmiarów majątku za pomocą instrumentów oceny procesów wewnątrzzakładowych mogących znaleźć zastosowanie w programach jednostek gospodarczych.

Raport kosztów produktów w rachunku ABC zawiera listę zapotrzebowania materiałowego i zapotrzebowania na działania w odniesieniu do określonych produktów. Źródłem informacji o działaniach niezbędnych do wytwarzania każdego produktu lub zlecenia jest lista zapotrzebowania na działania. Zawiera ona opisane dla poszczególnych produktów: zlecenia sekwencji działań podejmowanych w celu wykonania wyrobu gotowego, kwantytatywnie opisane zużycie poszczególnych działań, koszty działań niezbędnych do wytworzenia produktów i koszty poszczególnych działań na jednostkę produktu. W rachunku kosztów działań uwzględnia się działania oraz nośniki i koszty działań, w odróżnieniu od tradycyjnego raportu w kalkulacji doliczeniowej czy wielostopniowej, gdyż na liście zapotrzebowania na działania nie ma zaszeregowania kosztów pośrednich. W przedsiębiorstwach produkcyjnych często występuje produkcja w toku odzwierciedlona w remanencie końcowym, co oznacza, że działania podejmowane są w procesie produkcji. W rachunku kosztów działań wielkości poszczególnych grup przeliczane są na jednostki ekwiwalentne. Raport produkcji dotyczący produkcji w toku zawiera wielkości dla poszczególnych materiałów i działań na poziomie jednostki produktu oraz na poziomie serii. Zestawianie to ma również za zadanie rozliczanie kosztów materiałów i działań (Piosik 2006, s. 288).

Analiza występujących współzależności działań i procesów, niezbędna do stworzenia modelu ABC, jest także źródłem informacji o zaangażowaniu zasobów wykorzystywanych w poszczególnych fazach procesów wykonywania produktu w przedsiębiorstwie. Skonstruowanie modelu dostarcza kadrze zarządzającej wielu informacji wykorzystywanych w celu unikania zbędnych działań, reorganizacji i uproszczenia procesów funkcjonujących w przedsiębiorstwie (Witkowski 2007, s. 1; Śliwiński 2008, s. 14-18).

Wyniki analizy rachunku $\mathrm{ABC}$ w odniesieniu do asortymentu produkcji dają możliwość wskazania produktów rentownych i nierentownych. Na wysokość kosztu związanego z wyprodukowaniem asortymentu znaczny wpływ mają m.in. takie koszty, jak: koszty dostaw, magazynowania, działań wykonywanych $\mathrm{w}$ trakcie procesu produkcji. Wyniki analizy z zastosowaniem rachunku działań pozwalają na pogrupowanie produktów charakteryzujących się przewagą kosztów nad możliwą do uzyskania marżą. Wskazanie procesów, w wyniku których wytwarzane są nierentowne asortymenty, oraz określenie kosztochłonnych czynności 
stwarza możliwość podejmowania działań zmierzających do poprawy rentowności produkcji. Kadra zarządzająca może prowadzić takie działania korygujące, jak: eliminacja produktów, ustalenie nowej ceny, zastąpienie produktów substytutami, udoskonalenie procesu produkcyjnego, zainwestowanie w nowoczesne technologie czy zmiana polityki i strategii działania (Kaplan i Cooper 2000, s. 256-257). Eliminowanie nierentownych produktów powinno być przeprowadzone wyłącznie po wykorzystaniu wszystkich innych możliwości poprawy rentowności. W przeciwnym wypadku spowoduje to wzrost kosztów niewykorzystywanych mocy produkcyjnych w przedsiębiorstwie.

Na podstawie uzyskiwanej z modelu informacji o zyskowności klientów podejmowane są różnego rodzaju decyzje, w zależności od tego, w jaki sposób w wyniku analizy pogrupowani zostali klienci - czy zostali zaliczeni do grupy klientów rentownych, działających na granicy rentowności czy nierentownych. Posiadając informację o rzeczywistej rentowności, można stwarzać lepsze warunki współpracy z klientami rentownymi, a także odpierać próby przejęcia takich klientów przez konkurencję (Rybicka 2011, s. 437-438). Analiza współpracy z klientami stwarza możliwość przesunięcia niektórych klientów do grupy klientów rentownych, np. poprzez ustalenie nowej ceny usług, na podstawie rzeczywistych kosztów obsługi nietypowych zamówień czy zleceń, możliwość negocjacji warunków współpracy, np. obniżenie kosztów.

\section{Analiza ABC dotycząca wybranego przedsiębiorstwa}

Opracowanie systemu ABC dla badanego przedsiębiorstwa produkcyjno-usługowego wytwarzającego mrożonki należało rozpocząć od analizy wartości procesu gospodarczego. Polegała ona na systematycznym rozpatrywaniu czynności koniecznych do wykonania wyrobów gotowych i usług. W wyniku analizy zostały zdefiniowane wszystkie działania oraz określone działania zwiększające wartość wyrobu i usługi dla klienta, a także działania nieprzyczyniające się do wzrostu wartości produktu. Według autorki do wzrostu wartości użytkowej przyczynia się faktyczny przerób materiałów, a inne działania, takie jak: magazynowanie materiałów, przemieszczanie materiałów na stanowiska robocze, oczekiwanie na obróbkę czy kontrola, nie mają wpływu na wartość w tym sensie, że zużywają zasoby, nie zwiększając wartości produktu gotowego. W analizie wartości procesu gospodarczego wykorzystano zasady postępowania i techniki typowe dla tej metody. Został przygotowany szczegółowy wykaz udokumentowanych czynności związanych z produkcją danego wyrobu, począwszy od zamówienia i otrzymania materiałów, a skończywszy na ostatecznej kontroli jakości oraz przygotowaniu do sprzedaży. Następnie w wyniku dokładnej analizy ustalono, że skrócenie czasu 
trwania czynności nie powoduje zmiany wartości produktu. W takim przypadku należy podejmować starania w celu wdrożenia zmian procesu gospodarczego.

Konsekwencją przeprowadzenia analizy było opracowanie wykazu działań w przedsiębiorstwie produkcyjno-usługowym, którym został objęty rachunek ABC. Wykaz taki nazywany jest słownikiem działań i procesów ABC. Analiza wartości procesu na potrzeby wyodrębnienia działań i wdrożenia systemu ABC daje podstawę do podjęcia działań racjonalizatorskich, prowadzących do obniżki kosztów wytworzenia.

Analizę wartości procesu w badanym przedsiębiorstwie przedstawiono na rys. 1. Analiza wartości produkcji i sprzedaży dla mrożonek truskawek wykazała, że przy dotychczasowych rozwiązaniach organizacyjnych całkowity czas tego procesu wynosi średnio 4440 godz. (186 dni), a działania zwiększające wartość stanowią $1,8 \%$ tego czasu. Po dokładnym przeanalizowaniu cząstkowych procesów całkowity czas można ograniczyć do 4413 godz. (184 dni). Wskutek skrócenia czasu wykonywania czynności zwiększających wartość, przede wszystkim czasu oczekiwania wyrobu (segregacji, schładzania oraz mycia), dzięki zastosowaniu nowej linii produkcyjnej łączącej kilka podprocesów następuje znaczne zmniejszenie kosztów produkcji w ciągu roku obrotowego. Powyższe wyliczenia zostały oparte na następujących założeniach: skup owoców w jednym dniu, przyjmując do wyliczeń 6 godz., proces schładzania i mycia owoców przy założeniu 8 ton półproduktu, a także 6-miesięczny średni czas magazynowania, co wyniosło łącznie 4320 godz.

Należy podkreślić, że rezygnacja z działania lub skrócenie czasu wykonania czynności nie mogą dotyczyć tych procesów, które zmniejszyłyby satysfakcję klientów nabywających wyrób.

Po etapie analizy wartości wyodrębniono części procesu gospodarczego jednostki, w odniesieniu do których zarządzający wymagają przygotowania raportów wewnętrznych o wielkości poniesionych kosztów. W tabeli 1 przedstawiono wyodrębnione wszystkie procesy w przedsiębiorstwie produkcyjno-usługowym. Części te stanowią centra działań, które dla uproszczenia nazywane są działaniami lub procesami. Centrum działań obejmuje kilka ściśle powiązanych ze sobą rodzajów czynności. Przykładowymi działaniami o szerokim znaczeniu możliwymi do wydzielenia w przedsiębiorstwie są: obsługa dostaw produktów, transport wewnętrzny, kontrola jakości, obsługa sprzedaży wyrobów gotowych, rachunkowość i przetwarzanie danych, zabezpieczenie zakładu, administracja ogólna i zarządzanie, utrzymanie maszyn w ruchu.

Prawidłowe wyodrębnienie działań w przedsiębiorstwie ma wpływ na wytwarzane produkty (rodzaj i jakość produktów) i wymagania klientów, a zatem jest ważnym etapem determinującym kolejne fazy koncepcji ABC i wyniki kalkulacji. Pomocna w tym zakresie jest klasyfikacja działań opracowana przez R. Coopera 


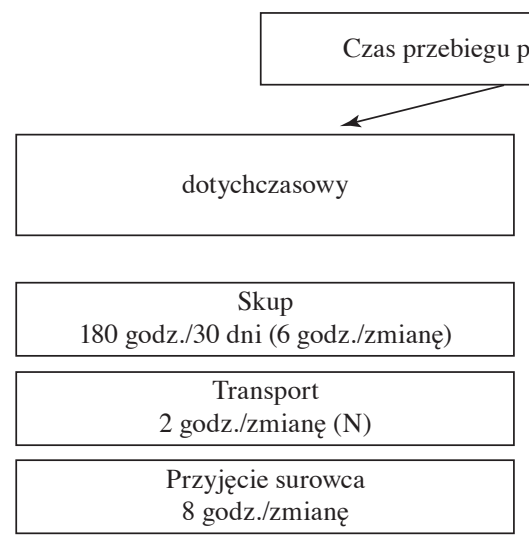

Schładzanie i mycie surowca

0-20 godz. (łącznie z myciem

24 ton surowca/dobę) $(\mathrm{Z})$

\begin{tabular}{c} 
Mrożenie \\
24 godz./dobę (Z) \\
\hline
\end{tabular}

Segregacja i pakowanie

maks. 24 godz./3 zmiany (łącznie

z pakowaniem dotyczy 8 ton/8 godz.) (Z)

\begin{tabular}{c} 
Magazyn \\
17520 godz. (maks. okres 24 miesiące) $(\mathrm{N})$ \\
\hline
\end{tabular}

\begin{tabular}{|c|}
\hline $\begin{array}{c}\text { Segregacja i pakowanie } \\
16 \text { godz. (łącznie } \\
\text { z pakowaniem/2 zmiany) }(\mathrm{Z})\end{array}$ \\
\hline $\begin{array}{c}\text { Detektor } \\
8 \text { godz./zmianę }(\mathrm{Z})\end{array}$ \\
\hline
\end{tabular}

\begin{tabular}{|c|}
\hline Wysyłka \\
24 godz. (według odbiorcy) (N) \\
\hline Transport \\
Transport zapewnia klient (N) \\
\hline
\end{tabular}

Odbiór

Całkowity czas do momentu sprzedaży 186 dni, w tym działania:

zwiększające wartość (Z) - 80 godz. (4 dni), niezwiększające wartości (N) - 4360 godz. (182 dni) po dokonaniu zmian

w wyniku analizy wartości

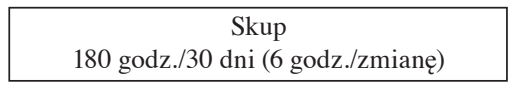

\begin{tabular}{c} 
Transport \\
2 godz./zmianę $(\mathrm{N})$ \\
\hline
\end{tabular}

\begin{tabular}{c} 
Przyjęcie surowca \\
8 godz./zmianę \\
\hline
\end{tabular}

Schładzanie i mycie surowca

0-20 godz. (łącznie z myciem

50 ton surowca/dobę) (Z)

\begin{tabular}{c} 
Mrożenie \\
24 godz./dobę (Z) \\
\hline
\end{tabular}

Segregacja i pakowanie

maks. 8-10 godz./dobę (łącznie

z pakowaniem dotyczy 8 ton/8 godz.) (Z)

\begin{tabular}{c} 
Magazyn \\
17520 godz. (maks. okres 24 miesiące) $(\mathrm{N})$ \\
\hline
\end{tabular}

\begin{tabular}{|c|}
\hline $\begin{array}{c}\text { Segregacja i pakowanie } \\
8 \text { godz. (łącznie } \\
\text { z pakowaniem/zmianę) }(\mathrm{Z})\end{array}$ \\
\hline $\begin{array}{c}\text { Detektor } \\
8 \text { godz./zmianę }(\mathrm{Z})\end{array}$ \\
\hline
\end{tabular}

\begin{tabular}{|c|}
\hline $\begin{array}{c}\text { Wysyłka } \\
24 \text { godz. (według odbiorcy) (N) }\end{array}$ \\
\hline $\begin{array}{c}\text { Transport } \\
\text { Transport zapewnia klient }(\mathrm{N})\end{array}$ \\
\hline
\end{tabular}

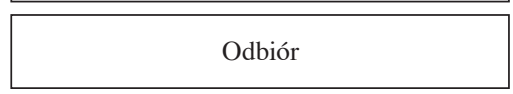

Całkowity czas do momentu sprzedaży 184 dni, w tym działania:

zwiększające wartość (Z) - 51 godz. (4 dni), niezwiększające wartości (N) - 4360 godz. (182 dni)

\section{Rys. 1. Analiza wartości procesu dla mrożonek truskawek}

Źródło: opracowanie własne na podstawie dokumentów badanego przedsiębiorstwa. 
i R.S. Kaplana, która pozwala na wyodrębnienie kilku różnych poziomów alokacji kosztów, czyli różnych poziomów działań (tabela 2). Wyodrębnionym poziomom działań zostały przyporządkowane odpowiadające im zasoby i szczegółowe czynności.

Tabela 1. Procesy podstawowe, pomocnicze i zarządcze w przedsiębiorstwie

\begin{tabular}{|l|l|l|}
\hline \multicolumn{1}{|c|}{ Procesy podstawowe } & \multicolumn{1}{|c|}{ Procesy zarządcze } & \multicolumn{1}{c|}{ Procesy pomocnicze } \\
\hline Produkcja & Zarządzanie zasobami & Obsługa księgowa \\
Sprzedaż & ludzkimi & Obsługa informatyczna \\
Marketing & Zarządzanie strategiczne & Kontrola pracy \\
Kontrola jakości & Zarządzanie jakością & Magazynowanie \\
Transport zewnętrzny & Zarządzanie produkcją & Technologia \\
Reklamacja & & \\
Zakup/zaopatrzenie & & \\
Obsługa klientów & & \\
\hline
\end{tabular}

Źródło: opracowanie własne.

Tabela 2. Działania i zasoby związane z kosztami operacyjnymi przedsiębiorstwa

\begin{tabular}{|c|c|}
\hline Rodzaje działań & Zasoby i szczegółowe czynności \\
\hline $\begin{array}{l}\text { Działania dotyczące całego } \\
\text { przedsiębiorstwa }\end{array}$ & $\begin{array}{l}\text { - zarządzanie przedsiębiorstwem } \\
\text { - utrzymanie budynków i gruntów } \\
\text { - ochrona } \\
\text { - oświetlenie i ogrzewanie }\end{array}$ \\
\hline Działania dotyczące rodzaju produktu & $\begin{array}{l}\text { - obsługa techniczna procesu produkcji } \\
\text { - opis techniczny produktów } \\
\text { - zmiany w technice produkcji } \\
\text { - udoskonalenie produktu }\end{array}$ \\
\hline Działania dotyczące partii produktu & $\begin{array}{l}\text { - przygotowanie produkcji } \\
\text { - przemieszczanie materiałów (transport wewnętrzny) } \\
\text { - zlecenie zakupu } \\
\text { - nadzór } \\
\text { - kontrola }\end{array}$ \\
\hline $\begin{array}{l}\text { Działania dotyczące jednostki } \\
\text { produktu }\end{array}$ & $\begin{array}{l}\text { - czas pracy bezpośredniej } \\
\text { - materiały bezpośrednie } \\
\text { - utrzymanie maszyn w ruchu } \\
\text { - energia (technologiczna) }\end{array}$ \\
\hline
\end{tabular}

Źródło: opracowanie własne na podstawie dokumentów badanego przedsiębiorstwa.

Prawidłowo ustalone centra działań, metody pomiaru kosztów i jednostki pomiaru wielkości działań są elementami systemu rachunku kosztów działań oraz określają zasady ewidencji faktycznych kosztów przeprowadzanych procesów 
gospodarczych. Warunkują one zasady budżetowania i analizy kosztów oraz odchyleń od tych zasad.

Po dokonaniu pomiaru i po pogrupowaniu kosztów według działań, co stanowi pierwszy etap rachunku kosztów ABC, przeprowadza się kalkulację kosztów produktów, tj. ustalenie kosztów w przekroju podmiotowym - jest to drugi etap rachunku kosztów działań. Rozliczenie kosztów pośrednich poszczególnych działań na rodzaje wytwarzanych produktów, a następnie ustalenie kosztów jednostkowych produktów wymaga obliczenia:

- stawki kosztów określonych działań,

- liczby jednostek danego działania, wydatkowanych lub planowanych na wytworzenie poszczególnych rodzajów produktów,

- kosztów działań obciążających poszczególne rodzaje produktów jako iloczynu stawki kosztów i miary działania.

Tabela 3. Dane dotyczące kosztów i wielkości produkcji w badanym przedsiębiorstwie w 2015 r.

\begin{tabular}{|c|c|c|c|}
\hline \multirow{2}{*}{ Kategoria kosztów } & \multicolumn{3}{|c|}{ Koszty } \\
\hline & truskawki & maliny & jagody \\
\hline $\begin{array}{l}\text { Koszty bezpośrednie }(\mathrm{w} \mathrm{zł} / 25 \mathrm{~kg})^{\mathrm{a}} \text { : } \\
\text { - produkty }\end{array}$ & 50 & 75 & 140 \\
\hline - płace $\mathrm{z}$ narzutami ${ }^{\mathrm{b}}$ & 30 & 45 & 84 \\
\hline $\begin{array}{l}\text { Koszty pośrednie (w zł): } \\
\text { - amortyzacja }\end{array}$ & \multicolumn{3}{|c|}{87390,20} \\
\hline - zużycie materiałów i energii & \multicolumn{3}{|c|}{2073898,07} \\
\hline - usługi obce & \multicolumn{3}{|c|}{115344,06} \\
\hline - podatki i opłaty & \multicolumn{3}{|c|}{24787,13} \\
\hline - wynagrodzenia & \multicolumn{3}{|c|}{205379,16} \\
\hline - ubezpieczenia & \multicolumn{3}{|c|}{48622,00} \\
\hline - pozostałe koszty rodzajowe & \multicolumn{3}{|c|}{46653,72} \\
\hline - razem koszty pośrednie & \multicolumn{3}{|c|}{2602074,33} \\
\hline Wielkość produkcji (w kg) ${ }^{\mathrm{c}}$ & 300000000 & 400000000 & 200000000 \\
\hline
\end{tabular}

Objaśnienia: a ceny owoców za 1 kg przyjęto następująco: truskawki 2 zł, maliny 3 zł, jagody 5,60 zł, ${ }^{\mathrm{b}}$ płace z narzutami stanowią $60 \%$ kosztu produktu, ${ }^{\mathrm{c}}$ wielkości szacowane ze względu na brak danych. Źródło: opracowanie własne.

Elementy rachunku kosztów działań oraz kolejne czynności niezbędne do obliczenia kosztu jednostkowego produktów zaprezentowano w tabelach 4-8. Dane dotyczą 2015 r. i zostały przedstawione tylko dla trzech produktów spośród 
dwudziestu możliwych, dlatego koszty zostały pomniejszone proporcjonalnie ${ }^{1}$. Dla każdej pozycji kosztów rodzajowych, będących odzwierciedleniem zużycia określonych zasobów przedsiębiorstwa, zdefiniowano nośniki kosztów zasobów (tabela 4).

Tabela 4. Koszty zasobów i ich nośniki

\begin{tabular}{|l|l|}
\hline \multicolumn{1}{|c|}{ Koszty } & \multicolumn{1}{c|}{ Nośniki kosztów zasobów } \\
\hline Amortyzacja & Powierzchnia hali produkcyjnej $\left(\mathrm{w} \mathrm{m}^{2}\right)$ \\
\hline Zużycie materiałów i energii & Ilość zużytych produktów $(\mathrm{w} \mathrm{kg})$ \\
\hline Usługi obce & Liczba wykonanych usług \\
\hline Wynagrodzenia & Liczba etatów \\
\hline Ubezpieczenia & Ubezpieczona powierzchnia $\left(\mathrm{w} \mathrm{m}^{2}\right)$ \\
\hline
\end{tabular}

Źródło: opracowanie własne.

W przedsiębiorstwie zdefiniowano osiem podstawowych działań, dla których opracowano odpowiednie nośniki kosztów (tabela 5).

Tabela 5. Działania i nośniki ich kosztów

\begin{tabular}{|l|l|}
\hline \multicolumn{1}{|c|}{ Działania } & \multicolumn{1}{c|}{ Nośniki kosztów działań } \\
\hline Dostarczanie materiałów & Liczba serii \\
\hline Kontrola jakości & Liczba kontroli \\
\hline Transport wewnętrzny & Liczba sztuk \\
\hline Wysyłka produktów & Liczba partii \\
\hline Utrzymanie wydziału & Powierzchnia $\left(\mathrm{w} \mathrm{m}^{2}\right)$ \\
\hline Zarządzanie produkcją & Liczba osób \\
\hline Produkcja & Liczba zleceń produkcyjnych \\
\hline Magazynowanie & Liczba dostaw \\
\hline
\end{tabular}

Źródło: opracowanie własne.

W kolejnym etapie dokonano analizy relacji zachodzących pomiędzy kosztami i działaniami odpowiedzialnymi za powstanie tych kosztów. Wynikiem prac jest macierz ZDZ, w której procentowo określono zapotrzebowanie działań na zasoby (tabela 6). Przykładowo działanie „produkcja” wykazało zapotrzebowanie

${ }^{1}$ Opracowanie jest wstępem do rozważań na temat wykorzystywania koncepcji ABC w różnych podmiotach sektora owocowo-warzywnego. Należy podkreślić, że pomocne w wyodrębnianiu procesów/działań są zakresy czynności poszczególnych pracowników, opisy stanowisk pracy oraz zadań nakładanych na dany dział/komórkę organizacyjną podmiotu gospodarczego. 
na $45 \%$ ogólnego zużycia materiałów pośrednich, spowodowało to 44\% kosztów amortyzacji, a także 15\% kosztów usług obcych (np. energia elektryczna) oraz 4\% kosztów ubezpieczeń. Dzięki zebranym informacjom możliwe jest określenie w dalszej kolejności całkowitych kosztów poszczególnych działań (tabela 7).

Tabela 6. Macierz zależności: zasoby - działania (dane w \%)

\begin{tabular}{|l|c|c|c|c|c|}
\hline \multirow{2}{*}{\multicolumn{1}{c|}{ Działania }} & \multicolumn{5}{|c|}{ Koszty (zasoby) } \\
\cline { 2 - 6 } & amortyzacja & $\begin{array}{c}\text { zużycie } \\
\text { materiałów } \\
\text { i energii }\end{array}$ & usługi obce & $\begin{array}{c}\text { wynagro- } \\
\text { dzenia }\end{array}$ & $\begin{array}{c}\text { ubezpie- } \\
\text { czenia }\end{array}$ \\
\hline Dostarczanie materiałów & 2 & - & 14 & 6 & - \\
\hline Kontrola jakości & - & - & - & 20 & - \\
\hline Transport wewnętrzny & 23 & 17 & 16 & 21 & 18 \\
\hline Wysyłka produktów & - & - & 15 & 6 & - \\
\hline Utrzymanie wydziału & 12 & 9 & 31 & 19 & 61 \\
\hline Zarządzanie produkcją & 6 & - & - & 12 & 17 \\
\hline Produkcja & 44 & 45 & 15 & 16 & 4 \\
\hline Magazynowanie & 13 & 29 & 9 & - & 17 \\
\hline
\end{tabular}

Źródło: opracowanie własne.

Tabela 7. Całkowite koszty działań

\begin{tabular}{|l|c|c|c|c|c|c|}
\hline \multirow{2}{*}{ Wyszczególnienie } & \multicolumn{7}{|c|}{ Koszty (w zł) } \\
\cline { 2 - 8 } & $\begin{array}{c}\text { amorty- } \\
\text { zacja }\end{array}$ & $\begin{array}{c}\text { zużycie } \\
\text { materiałów } \\
\text { i energii }\end{array}$ & $\begin{array}{c}\text { usługi } \\
\text { obce }\end{array}$ & $\begin{array}{c}\text { wynagro- } \\
\text { dzenia }\end{array}$ & $\begin{array}{c}\text { ubezpie- } \\
\text { czenia }\end{array}$ & razem \\
\hline $\begin{array}{l}\text { Dostarczanie } \\
\text { materiałów }\end{array}$ & 174780 & - & 1614816 & 1232274 & - & 3021872 \\
\hline Kontrola jakości & - & - & - & 4107583 & - & 4107583 \\
\hline Transport wewnętrzny & 2009974 & 35256267 & 1845504 & 4312962 & 875195 & 44299905 \\
\hline Wysyłka produktów & - & - & 1730160 & 1232274 & - & 2962435 \\
\hline Utrzymanie wydziału & 1048682 & 18665082 & 3575665 & 3902204 & 2965941 & 30157576 \\
\hline $\begin{array}{l}\text { Zarządzanie } \\
\text { produkcją }\end{array}$ & 524341 & - & - & 2464549 & - & 2988891 \\
\hline Produkcja & 3845168 & 93325413 & 1730160 & 3286066 & 826573 & 103013383 \\
\hline Magazynowanie & 1136072 & 60143044 & 1038096 & - & 194487 & 62511701 \\
\hline Koszty pośrednie & 87390,20 & 2073898,07 & 115344,06 & 205379,16 & 48622,00 & 2530633,49 \\
\hline
\end{tabular}

Źródło: opracowanie własne. 
W następnym etapie kalkulacji ustalono, które działania są niezbędne do wytworzenia określonych wyrobów. Efektem tej analizy było stworzenie macierzy zależności: działania - produkty (DPZ), w której procentowo wyrażono udział działań w wytworzeniu poszczególnych wyrobów (tabela 8).

Tabela 8. Macierz zależności: działania - produkty (dane w \%)

\begin{tabular}{|c|c|c|c|c|c|c|c|c|}
\hline \multirow[b]{2}{*}{ Wyszczególnienie } & \multicolumn{8}{|c|}{ Działania } \\
\hline & 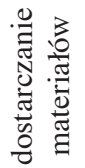 & 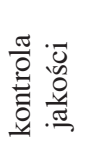 & 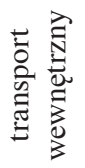 & 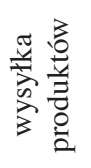 & 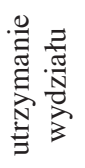 & 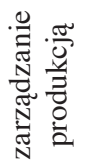 & $\begin{array}{l}\frac{\pi}{0} \\
\frac{y}{3} \\
0 \\
0 \\
0\end{array}$ & 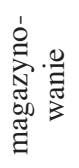 \\
\hline Truskawki & 45 & 24 & 45 & 30 & 36 & 35 & 48 & 12 \\
\hline Maliny & 35 & 14 & 27 & 35 & 34 & 35 & 40 & 16 \\
\hline Jagody & 30 & 14 & 21 & 30 & 29 & 30 & 45 & 15 \\
\hline
\end{tabular}

Źródło: opracowanie własne.

Korzystając z informacji i obliczeń wygenerowanych w poprzednich etapach, dokonano rozliczenia kosztów pośrednich na poszczególne wyroby. Jednostkowe koszty wytworzenia wyrobów są sumą jednostkowych kosztów bezpośrednich i jednostkowych kosztów pośrednich. Wyniki kalkulacji przedstawiono w tabeli 9.

Tabela 9. Koszty wytworzenia wyrobów w przedsiębiorstwie

\begin{tabular}{|l|c|c|c|c|}
\hline Wyszczególnienie & $\begin{array}{c}\text { Wielkość } \\
\text { produkcji } \\
\text { (szacowana) }\end{array}$ & $\begin{array}{c}\text { Koszty } \\
\text { bezpośrednie } \\
\text { (w zł/szt.) }\end{array}$ & $\begin{array}{c}\text { Jednostkowe } \\
\text { koszty pośrednie } \\
\text { (w zł) }\end{array}$ & $\begin{array}{c}\text { Jednostkowy } \\
\text { koszt } \\
\text { wytworzenia } \\
\text { (w zł) }\end{array}$ \\
\hline Truskawki & 300000000 & 80,00 & 30,59 & 110,59 \\
\hline Maliny & 400000000 & 120,00 & 21,36 & 141,36 \\
\hline Jagody & 200000000 & 224,00 & 65,54 & 289,54 \\
\hline
\end{tabular}

Źródło: opracowanie własne.

Przedsiębiorstwa stosują kalkulację opartą na działaniach, oczekując, że pomocna będzie w podejmowaniu lepszych decyzji, wpłynie na poprawę rentowności i umożliwi osiągnięcie większego zwrotu z zaangażowanych zasobów. Nakład pracy związany z kalkulacją kosztów działań i produktów zależy od wymaganego poziomu dokładności i szczegółowości. Im większe są wymagania w zakresie dokładności, tym więcej należy zgromadzić szczegółowych informacji. Zwiększenie szczegółowości danych nie decyduje jednak o poprawie dokładności kalku- 
lacji. Podstawowym celem kalkulacji w systemie ABC jest odpowiednia informacja. Kalkulacja w rachunku kosztów działań pozwala określić koszt wyrobów $\mathrm{z}$ dużą dokładnością. Z przedstawionych wyliczeń wynika, że jednostkowy koszt rzeczywisty przetwarzania truskawek wyniósł 110,59zł, malin - 141,36zł, a jagód - 289,54 zł. Rzeczywisty koszt wytworzenia ustalany jest jako suma kosztów materiałów bezpośrednich, kosztów robocizny bezpośredniej, kosztów pośrednich, do których zalicza się: koszt dostaw materiałów, koszty pośrednie przygotowania produkcji, koszty utrzymania maszyn oraz koszt kontroli jakości. Suma ta stanowi wielkość kosztów poniesionych na jednostkę produkcyjną.

\section{Podsumowanie}

Koncepcję rachunku kosztów działań można wykorzystywać w różnych sytuacjach, charakteryzuje ją bowiem elastyczność i możliwość adaptacji. Jak wynika $\mathrm{z}$ analizy studiów przypadków implementacji tego rachunku w różnych jednostkach gospodarczych, nie zawsze konieczne jest wdrożenie całego rachunku kosztów działań. Czasami wystarczą pewne jego moduły (np. wdrożenie w jednym ośrodku odpowiedzialności, w poszczególnych działach), aby określić słabe punkty jednostki gospodarczej.

Rozwinięcie koncepcji rachunku kosztów działań w odniesieniu do zarządzania kosztami działań oraz samymi działaniami daje możliwość wprowadzenia efektywnych metod zarządzania, co wpływa na usprawnianie procesów kontroli, podejmowania decyzji oraz planowania operacyjnego i strategicznego. Bariery wdrożenia rachunku kosztów działań to m.in.:

- brak odpowiednich miar, rzetelnie odzwierciedlających stopień realizacji zadań,

- centralizacja władzy i kompetencji,

- dublowanie zakresów działań, brak zakresów czynności i opisów stanowisk pracy,

- konieczność stworzenia odpowiedniego systemu komputerowego do ewidencji kosztów w układzie działań,

- istniejące ograniczenia finansowe.

Do głównych zalet rachunku kosztów działań należy zaliczyć (Kiziukiewicz 1999, s. 126):

- uzyskiwanie dokładniejszych informacji o kosztach,

- poznanie przyczyn powstawania kosztów,

- prowadzenie pogłębionych badań analitycznych,

- stworzenie podstaw decyzji strategicznych w zakresie polityki produkcji, świadczenia usług i kształtowania struktury działalności okołoprodukcyjnej, 
- elastyczność - odnoszenie kosztów nie tylko do produktów, ale również do innych obiektów kalkulacji, np. procesów,

- ukazanie miejsca i roli rachunku kosztów działań w zarządzaniu przedsiębiorstwem w gospodarce rynkowej.

Głównym celem opracowania była próba wdrożenia rachunku kosztów działań w wybranym przedsiębiorstwie branży owocowo-spożywczej oraz usystematyzowanie wiedzy dotyczącej kosztów i ich roli w funkcjonowaniu jednostki gospodarczej. Na podstawie literatury przedmiotu wskazano także teoretyczne aspekty dotyczące rachunku kosztów działań oraz możliwości określania procesów dla potrzeb budowania rachunku kosztów działań w przedsiębiorstwie. Analizowanie procesów odbywało się na podstawie zakresów czynności poszczególnych pracowników, którzy te czynności wykonywali. W świetle przeprowadzonych badań i własnych obserwacji potwierdzono tezę, że sprawność procesu gospodarczego zachodząca w jednostce gospodarczej zależy od efektywnego przebiegu wielu działań, a sterowanie tymi działaniami przyczynia się do redukowania kosztów prowadzonej działalności oraz zapewnienia efektywniejszego świadczenia usług.

Podsumowując, rachunek kosztów działań stwarza podstawy do budżetowania kosztów działań, usług i produktów oraz oceny rentowności produktów i klientów. Przyczynia się do kształtowania optymalnego poziomu produkcji i optymalizacji przebiegu procesów gospodarczych. Pozwala także na weryfikację polityki cenowej organizacji oraz kształtuje jednostkową cenę usługi, produktu czy wyrobu.

\section{Literatura}

Buk H. (2006), Nowoczesne zarzqdzanie finansami. Planowanie i kontrola, C.H. Beck, Warszawa.

Januszewski A. (2005), Stosowanie rachunku kosztów działań w polskich przedsiębiorstwach, „Controlling i Rachunkowość Zarządcza”, nr 1.

Kaplan R.S., Cooper R. (2000), Zarzqdzanie kosztami i efektywnościq, Oficyna Ekonomiczna, Dom Wydawniczy ABC, Kraków.

Kiziukiewicz T. (1999), Rachunkowość zarzqdcza, Ekspert, Wrocław.

Klimczuk Z. (2008), Na czym polega System Activity Based Costing i Activity Based Management (ABC/ABM), ,Biuletyn Rachunkowości” nr 6(54).

Naruć W., Nowak J., Wieloch M. (2008), Operacyjne planowanie finansowe - ujęcie praktyczne, Difin, Warszawa.

Piechota R. (2005), Projektowanie rachunku kosztów działań. Activity Based Costing, Difin, Warszawa.

Piosik A. (2006), Zasady rachunkowości zarzqdczej, PWN, Warszawa.

Rybicka K. (2011), Wykorzystywanie rachunku kosztów działań w przedsiębiorstwie produkcyjnym (w:) Rachunek kosztów i pomiar dokonań, red. E. Nowak, M. Nieplowicz, Wydawnictwo Uniwersytetu Ekonomicznego we Wrocławiu, Wrocław. 
Stępień K. (2011), Rachunek kosztów pełnych versus rachunek kosztów zmiennych (w:) Rachunek kosztów i pomiar dokonań, red. E. Nowak, M. Nieplowicz, Wydawnictwo Uniwersytetu Ekonomicznego we Wrocławiu, Wrocław.

Śliwiński B. (2008), Wdrażanie rachunku kosztów działań w małych i średnich przedsiębiorstwach, „Controlling i Rachunkowość Zarządcza”, nr 2.

Witkowski K. (2007), Jak w praktyce wykorzystywać wyniki analiz Activity Based Costing, „Controlling i Rachunkowość Zarządcza” nr 3.

\section{Activity-Based Costing in an Enterprise}

(Abstract)

Activity-based costing has become a very interesting and important issue. Still changing conditions and highly complicated production processes have rendered traditional accounting cost systems sometimes inadequate for making decisions. Managers are aware that they need cost accounting solutions that will quickly deliver them certain information. The aim of this article is to present the point of activity-based costing and to describe the principles of design and implementation of this costing method in Polish companies. It presents the results of research on the practical application of activity-based costing in an enterprise.

Keywords: management accounting, activity-based costing, ABC account, financial accounting, reporting. 